\title{
Pengaruh Model Pembelajaran Kooperatif Tipe Student Teams Achievment Division Terhadap Penguasaan Kompetensi Pengetahuan IPS
}

\author{
Ni Putu Adi Utami1 ${ }^{*}$, I G.A. Agung Sri Asri², I Gusti Agung Oka Negara3 \\ 1,2,3 Jurusan Pendidikan Guru Sekolah Dasar (PGSD), Universitas Pendidikan Ganesha, Singaraja, Indonesia.
}

\author{
A R T I C L E I N F O \\ Article history: \\ Received 12 February 2018 \\ Received in revised form \\ 17 March 2018 \\ Accepted 19 April 2018 \\ Available online 208 May \\ 2018 \\ Kata Kunci: \\ Otoriter, Demokratis, \\ Permisif, Nilai Agama \\ Moral, Sosial Emosional, \\ Bahasa, Kognitif, Fisik \\ Motorik \\ Keywords: \\ Authoritarian, Democratic, \\ Permissive, Religious Values \\ Moral, Social, Emotional, \\ Language, Cognitive, \\ Physical Motor
}

\begin{abstract}
A B S T R A K
Penelitian ini bertujuan untuk mengetahui perbedaan model pembelajaran kooperatif tipe Student Teams Achievment Division (STAD) dan pembelajaran konvensional pada penguasaan kompetensi pengetahuan IPS siswa kelas IV SD Negeri Gugus Pattimura Tahun Ajaran 2016/2017 pada tema Kayanya Negeriku. Penelitian ini merupakan penelitian eksperimen untuk membandingkan penguasaan kompetensi pengetahuan IPS siswa yang dibelajarkan dengan model pembelajaran kooperatif tipe STAD dan siswa yang dibelajarkan dengan pembelajaran konvensional menggunakan pendekatan saintifik. Rancangan penelitian yang digunakan adalah desain eksperimen semu dengan bentuk nonequivalent control group design. Populasi pada penelitian adalah seluruh siswa kelas IV SD Negeri Gugus Pattimura. Teknik pengambilan sampel menggunakan randoms sampling kemudian dilakukan uji kesetaraan pada sampel tersebut. Metode pengumpulan data dalam penelitian ini adalah metode tes. Kemudian dilanjutkan dengan uji prasyarat yang memperoleh hasil bahwa kelompok sampel berdistribusi normal dan memiliki varians yang homogen. Setalah uji prasyarat, dilakukan uji hipotesis dengan kriteria $t_{\text {hitung }} \leq t_{\text {tabel }}$ pada taraf signifikansi $5 \%$ dan $d k=38+40-2=76$ adalah 2,00. Berdasarkan hasil uji hipotesis diperoleh $t_{\text {hitung }}=2,64$, kemudian hasil $t_{\text {hitung }}$ dibandingkan dengan $t_{\text {tabel }}$ yang memperoleh hasil $t_{\text {hitung }}>t_{\text {tabel }}$. Kesimpulan dalam kegiatan penelitian ini adalah terdapat perbedaan signifikan penguasaan kompetensi pengetahuan IPS kelompok siswa
\end{abstract} yang dibelajarkan mengunakan model pembelajaran kooperatif tipe STAD dan kelompok siswa yang dibelajarkan menggunakan penembelajaran konvensional.

\section{A B S T R A C T}

This study aims to determine the differences of cooperative learning model of Student Teams Achievment Division (STAD) type and conventional learning on the competence of IPS knowledge of fourth grade students of SD Negeri Gugus Pattimura of the academic year 2016/2017 on the theme of Kayanya Negeriku. This study is an experimental study to compare IPS knowledge competence which is taught by cooperative learning model of STAD type and students who are taught by conventional learning using scientific approach. The research design used is a quasi-experimental design with noquivalent control group design. The population in the study were all fourth grade students of SD Negeri Gugus Pattimura. Sampling technique using randoms sampling then conducted equality test on the sample. Then proceed with a prerequisite test that obtains the result that the sample group is normally distributed and has a homogeneous variance. After the prerequisite test, the hypothesis test is done with the criterion $t_{\text {count }} \leq t_{\text {table }}$ at $5 \%$ significance level and $d k=38+40-2=76$ is 2.00 . Based on result of hypothesis test obtained tcount $=2,64$, then result of tcount compared with ttable that get result $t_{\text {count }}>t_{\text {table. }}$. The conclusion of this research is that there is a significant difference in the mastery of IPS knowledge competence of the group of students who are taught using STAD type cooperative learning model and the group of students who are taught using conventional learning.

Copyright (C) Universitas Pendidikan Ganesha. All rights reserved. 


\section{Pendahuluan}

Kegiatan pembelajaran di Indonesia berpedoman pada kurikulum. Menurut Malik (2012:16) kurikulum merupakan "sejumlah mata ajaran yang harus ditempuh dan dipelajari oleh siswa untuk memperoleh sejumlah pengetahuan". Pada Undang-Undang Nomor 20 Tahun 2003 memaparkan kurikulum merupakan seperangkat rencana dan pengaturan mengenai tujuan, isi, dan bahan pelajaran serta cara yang digunakan sebagai pedoman penyelenggaraan kegiatan pembelajaran untuk mencapai tujuan pendidikan tertentu. Lebih lanjut pada Permendikbud No. 57 tahun 2014 dijelaskan dua dimensi kurikulum, yang pertama adalah rencana dan pengaturan mengenai tujuan, isi, dan bahan pelajaran, sedangkan yang kedua adalah cara yang digunakan untuk kegiatan pembelajaran. Jadi, kurikulum adalah seperangkat rencana pengaturan mengenai tujuan, isi, dan bahan pelajaran mengenai cara yang digunakan untuk kegiatan pembelajaran agar siswa memperoleh sejumlah pengetahuan.

Kurikulum yang digunakan di Indonesia telah mengalami beberapa kali perubahan, saat ini kurikulum yang digunakan adalah Kurikulum 2013 yang merupakan penyempurnaan dari Kurikulum Tingkat Satuan Pendidikan (KTSP). Kegiatan pembelajaran pada Kurikulum 2013 di sekolah dasar dikemas menggunakan tema-tema yang berorientasi pada pendekatan saintifik. Pendekatan saintifik memiliki lima pengalaman belajar yang tercantum dalam Permendikbud No. 103 Tahun 2014, yaitu : (a) mengamati; (b) menanya; (c) mencoba/ mengumpulkan informasi; (d) menalar/ mengasosiasi; (e) membentuk jejaring (melakukan komunikasi). Keberadaan pendekatan saintifik dalam kegiatan pembelajaran Kurikulum 2013 bertujuan untuk mencapai kompetensi yang ada pada kegiatan pembelajaran. Kompetensi pembelajaran pada kurikulum 2013 memiliki rumusan Kompetensi Inti (KI). Pada Permendikbud Nomor 57 Tahun 2014 Kompetensi Inti (KI) yang memiliki rumusan notasi KI-1 untuk sikap spritual, KI-2 untuk sikap sosial, KI-3 untuk pengetahuan, dan KI-4 untuk keterampilan.

Kompetensi Inti pada kurikulum 2013 memiliki beberapa muatan materi pembelajaran, salah satunya adalah IPS. Ilmu Pengetahuan Sosial yang biasa disingkat dengan IPS merupakan salah satu muatan materi pembelajaran di sekolah dasar. Menurut Solihatin dan Raharjo (2012:14), "ilmu pengetahuan sosial membahas hubungan antara manusia dan lingkungannya". Pendapat tersebut diperkuat oleh pendapat Susanto (2015:137), yang menyatakan bahwa "IPS merupakan ilmu yang mengkaji berbagai disiplin ilmu sosial dan humaniora serta kegiatan dasar manusia yang dikemas secara ilmiah dalam rangka memberi wawasan dan pemahaman yang mendalam kepada peserta didik, khususnya di tingkat dasar dan menengah". Wulandari (2014) menyatakan bahwa Ilmu Pengetahuan Sosial (IPS) merupakan intregasi dari berbagai cabang ilmu-ilmu sosial seperti sosiologi, sejarah, geografi, ekonomi, politik, hukum, dan budaya. Selanjutnya menurut Gunawan (2016:48), "di sekolah dasar IPS merupakan suatu bahan kajian yang terpadu yang merupakan penyederhanaan, adaptasi, seleksi, modifikasi yang diorganisasikan dari konsep-konsep dan keterampilan sejarah, geografi, sosiologi, antropologi, dan ekonomi". Jadi, secara sederhana IPS di sekolah dasar adalah ilmu yang membahas hubungan antara manusia dan lingkungannya dengan penyederhanaan konsep-konsep ilmu sosial, disiplin ilmu sosial dan humaniora serta kegitan manusia yang dikemas secara ilmiah dalam rangka memberi wawasan dan pemahaman yang mendalam pada peserta didik.

Kegiatan pembelajaran pada muatan materi IPS perlu memperhatikan karakteristik dan kebutuhan siswa yang umumnya berbeda, namun dapat dikelompokkan berdasar jenjang pendidikan yang ditempuh. Menurut Sumantri (2015:154) karakteristik siswa usia sekolah dasar secara umum senang bermain, senang bergerak, senang bekerja dalam kelompok, senang melakukan atau memperagakan secara langsung. Pendapat Sumantri tersebut sejalan dengan yang dilihat oleh peneliti ketika melakukan observasi awal untuk mencari data siswa di SD Gugus Pattimura pada tanggal 3-6 Januari 2017. Melihat karakteristik siswa sekolah dasar, peneliti merasa perlu melakukan variasi pada kegiatan pembelajaran yang dapat menunjang karakteristik siswa.

Salah satu cara yang dapat dilakukan untuk memberikan variasi pada kegiatan pembelajaran adalah dengan mencoba menggunakan model pembelajaran kooperatif. Menurut Majid (2015:174), "pembelajaran kooperatif merupakan model pembelajaran yang mengutamakan kerja sama untuk mencapai tujuan". Selanjutnya, menurut Slavin (2016:10), "semua metode pembelajaran kooperatif menyumbangkan ide bahwa siswa yang bekerja sama dalam belajar dan bertanggung jawab teman satu timnya mampu membuat diri mereka belajar sama baiknya". Lebih lanjut Rusman (2014:202) menjelaskan bahwa "pembelajaran kooperatif merupakan pembelajaran dengan cara siswa belajar dan bekerja dalam kelompok-kelompok kecil secara kolaboratif yang anggotanya terdiri dari empat sampai enam orang dengan struktur kelompok yang bersifat heterogen". Menurut Yensy (2012) pembelajaran kooperatif adalah metode pembelajaran berkelompok, sehingga dapat mengaktifkan siswa sebab dalam kelompok mereka diharapkan dapat bekerja sama dan berdiskusi menyelesaikan tugas-tugas yang diberikan guru. Secara sederhana pembelajaran kooperatif adalah model pembelajaran yang 
mengutamakan kerja sama siswa dalam belajar dan bertanggung jawab pada kelompok-kelompok kecil dengan anggota empat sampai enam orang dengan strukur kelompok yang bersifat heterogen untuk mencapai suatu tujuan.

Model pembelajaran kooperatif memiliki beberapa variasi, salah satunya adalah Student Teams Achivment Division (STAD). Menurut Rusman (2014:213), "model STAD dikembangkan oleh Robert Slavin dan teman-temannya di Universitas John Hopkin dan telah digunakan dalam mata pelajaran matematika, IPA, IPS, bahasa inggris, teknik dan subjek lainnya pada tingkat sekolah dasar sampai perguruan tinggi". Selanjutnya menurut Slavin (2016:143), "kegiatan pembelajaran STAD terdiri atas lima komponen utama, yaitu persentasi kelas, tim, uis, skor kemajuan individual, dan rekognisi tim”. Lebih lanjut Bhoke (2016) menyatakan gagasan utama dibalik model STAD adalah memotivasi para siswa untuk mendorong dan membantu satu sama lain untuk menguasai keterampilan-keterampilan yang disajikan oleh guru. Menurut Utami (2015) ide utama pembelajaran metode STAD adalah untuk memotivasi siswa agar saling membantu dalam memahami sebuah materi pelajaran dan saling membantu dalam menyelesaikan masalah. Salah satu hal yang didapatkan dalam mencoba penggunaan model pembelajaran kooperatif tipe STAD yang dinyatakan oleh Giantara (2014) adalah suasana lingkungan dapat dikondisikan senyaman mungkin bagi siswa dalam proses pembelajaran. Menurut Lasia (2014) pengelolaan pembelajaran dengan model kooperatif tipe STAD memiliki tiga tujuan yang ingin dicapai yaitu, meningkatkan kinerja siswa dalam tugastugas akademik, agar siswa mau mengakui adanya keberagaman dan mengembangkan keterampilan siswa.

Penelitian yang dilakukan Sudiarpa (2015) menyimpulkan bahwa terdapat perbedaan hasil belajar IPA siswa yang signifikan antara siswa yang belajar dengan menggunakan model pembelajaran kooperatif tipe STAD dan siswa yang belajar dengan menggunakan model pembelajaran konvensional. Selain itu, penelitian yang dilakukan oleh Sudiarsini (2016) menyimpulkan bahwa terdapat pengaruh model pembelajaran kooperatif tipe STAD berbantuan media audiovisual terhadap hasil belajar IPA kelas V SD Gugus IV Kecamatan Sawan. Berdasarkan teori model pembelajaran kooperatif tipe STAD dan didukung penelitian yang relevan, maka dilaksanakan kegiatan penelitian eksperimen dengan judul : "Pengaruh Model Pembelajaran Kooperatif tipe Students Teams Achievment Divisions Terhadap Penguasaan Kompetensi Pengetahuan IPS Kelas IV SD Gugus Pattimura Tahun Ajaran 206/2017”.

\section{Metode}

Kegiatan penelitian dilaksanakan di SD Gugus Pattimura, siswa kelas IV semester genap Tahun Ajaran 2016/2017 digunakan sebagai objek penelitian. Penelitian yang dilakasanakan merupakan jenis penelitian kuantitatif dengan desain penelitian eksperimen semu (quasy eksperiment). Desain penelitian ini memiliki kelompok kontrol tetapi tidak dapat berfungsi sepenuhnya mengontrolvariabel-veriabel luar yang dapat mempengaruhi kegiatan penelitian. Desain eksperimen semu yang digunakan dalam penelitian ini adalah bentuk non-equivalent control group desain.

Rancangan penelitian berhubungan dengan suatu variabel penelitian dalam perlakuan yang diberikan. Variabel penelitian dalam perlakuan yang diberikan melibatkan variabel bebas yang dimanipulasi. Variabel bebas sering juga disebut variabel independen atau prediktor. Variabel bebas dalam penelitian ini adalah model pembelajaran kooperatif tipe STAD yang digunakan pada kelas eksperimen dan pembelajaran konvensional dengan menggunakan pendekatan saintifiik pada kelas kontrol. Variabel terikat dalam penelitian ini adalah penguasaan kompetensi pengetahuan IPS siswa kelas IV sekolah dasar.

Populasi pada penelitian ini terbatas pada siswa kelas IV SD Negeri Gugus Pattimura Tahun Ajaran 2016/2017, yang terdiri dari delapan kelas yang tersebar pada lima sekolah. Pada Gugus Pattimura terdapat SD Negeri 3 Sesetan, SD Negeri 1 Sesetan, SD Negeri 7 Sesetan, SD Negeri 11 Sesetan, dan SD Negeri 18 Sesetan. Jumlah populasi dari penelitian ini adalah 322 siswa, dengan rincian pada tabel berikut. Siswa kelas IV pada SD Negeri 3 Sesetan berjumlah 100 orang, SD Negeri 1 Sesetan berjumlah 71 orang, SD Negeri 7 Sesetan berjumlah 73 orang, SD Negeri 11 Sesetan berjumlah 40 orang, dan SD Negeri 18 Sesetan berjumlah 38 orang.

Pengambilan sampel dalam kegiatanpenelitian ini dilakukan dengan teknik random sampling. Pengambilan sampel dilakukan dengan cara setiap kelas yang ada dalam populasi diberi nomor urut terlebih dahulu kemudian dilakukan random dan diambil 2 kelas sebagai sampel. Sampel yang diperoleh dari hasil random adalah kelas siswa IV SD Negeri 11 Sesetan berjumlah 40 orang dan siswa kelas IV SD Negeri 18 Sesetan berjumlah 38 orang. Uji prasyarat analisis yang dilakukan pertama sebelum uji-t yaitu uji normalitas nilai pretest sampel penelitian. Hasil uji normalitas pada sampel siswa kelas IV SD Negeri 11 Sesetan menunjukkan $\mathrm{X}^{2}$ hitung sebesar 7,48 dan pada siswa kelas IV SD Negeri 18 Sesetan menunjukkan $\mathrm{X}^{2}$ hitung sebesar 5,58. Hasil $\mathrm{X}^{2}$ hitung tersebut dibandingkan $\mathrm{X}^{2}$ tabel pada taraf signifikansi 5\% sebesar 11,07. 
Berdasarkan hal tersebut maka diperoleh bahwa $\mathrm{X}^{2}$ hitung $<\mathrm{X}^{2}$ tabel yang artinya data penguasaan kompetensi pengetahuan IPS pada kedua sampel tersebut bersitribusi normal.

Setelah menganalisis uji normalitas, selanjutnya dilakukan pengujian homogenitas. Hasil uji normalitas pada sampel siswa kelas IV SD Negeri 11 Sesetan dan SD Negeri 18 Sesetan menunjukkan

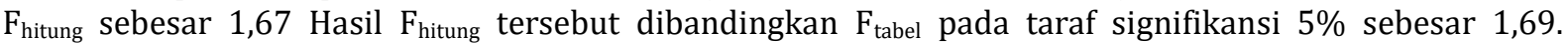
Berdasarkan hal tersebut maka diperoleh bahwa $\mathrm{F}_{\text {hitung }}<\mathrm{F}_{\text {tabel }}$ yang artinya data dinyatakan homogen. Setelah data nilai pretest kedua kelompok dinyatakan berdistribusi normal dan homogen, analisis dilanjutkan dengan penyetaraan sampel menggunakan uji-t. Kesetaraan sampel diuji dengan rumus uji-t yakni bentuk polled varian karena jumlah $\mathrm{n}_{1} \neq \mathrm{n}_{2}$. Hasil thitung diperoleh 0,33 pada taraf signifikansi $5 \%$ dengan $\mathrm{dk}=40+3-2=76$, diperoleh $\mathrm{t}_{\text {tabel }}$ sebesar 2,00. Berdasarkan hasil analisis berarti $t_{\text {hitung }}(0,33)<$ $t_{\text {tabel }}(2,00)$ yang menyatakan bahwa kedua kelompok sampel setara.

Data yang diperlukan dalam penelitian ini dikumpulkan dengan metode tes. Jenis instrumen yang digunakan pada penelitian ini berupa tes objektif dalam benuk pilhan ganda biasa dengan 4 pilihan jawaban (a,b,c,d) sejumlah 40 butir. Tes objektif yang akan digunakan diuji coba terlebih dahulu pada kelas yang lebih tinggi dari kelas yang diteliti, yaitu diuji coba pada kelas V. Data yang dihasilkan melalui tes pilihan ganda tersebut berupa angka. Pemeriksaan hasil tes siswa dilakukan berdasarkan kunci jawaban yang benar. Skor 0 diberikan untuk siswa yang menjawab salah dan skor 1 untuk siswa yang menjawab benar pada setiap butir tes. Jadi skor setiap jawaban dijumlahkan dan jumlah tersebut menjadi skor variabel penguasaan kompetensi pengetahuan IPS. Penilaian pada hasil tes menggunakan skala 100. 0 merupakan skor minimal dan 100 merupakan skor maksimal tes penguasaan kompetensi pengetahuan IPS.

Data penguasan kompetensi pengetahuan IPS diperoleh dengan menyiapkan instrumen penguasaan kompetensi pengetahuan IPS. Instrumen disusun berdasarkan kisi-kisi dan dilakukan uji validitas, daya beda, tingkat kesukaran, dan reliabilitas. Berdasarkan uji validias, daya beda, tingkat kesukaran dan reliabilitas diperoleh 20 butir soal yang akan digunakan untuk mengukur penguasaan kompetensi pengetahuan IPS kelas IV.

\section{Hasil dan Pembahasan}

Data hasil penelitian yang diperoleh merupakan nilai penguasaan kompetensi pengetahuan IPS siswa kelas IV yang diberlajarkan menggunakan model pembelajaran kooperatif tipe STAD dan siswa kelas IV yang dibelajarkan melalui pembelajaran konvensional menggunakan pendekatan saintifik.

Tabel 1. Rekapitulasi Hasil Perhitungan Nilai Penguasaan Kompetensi Pengetahuan IPS

\begin{tabular}{ccc}
\hline Data Statistik & \multicolumn{2}{c}{ Hasil Penguasaan Kompetensi Pengetahuan IPS } \\
& Kelompok Eksperimen & Kelompok Kontrol \\
\hline Mean & 78,29 & 73,38 \\
$\mathrm{~S}^{2}$ & 80,83 & 54,41 \\
$\mathrm{~S}$ & 8,99 & 7,38 \\
\hline
\end{tabular}

Data hasil penelitian menunjukkan bahwa mean nilai penguasaan kompetensi pengetahuan IPS siswa pada kelompok eksperimen yang dibelajarkan dengan menggunakan model pembelajaran kooperatif tipe $S T A D$ lebih tinggi yaitu 78,29 daripada mean nilai penguasaan kompetensi pengetahuan IPS siswa kelompok kontrol yaitu 73,38. Mean pada kelompok eksperimen dikategorikan kedalam Penilaian Acuan Patokan (PAP) skala lima dan menunjukkan kategori baik. Apabila nilai kelompok eksperimen divisualisasikan ke dalam bentuk diagram batang maka tampak pada gambar berikut.

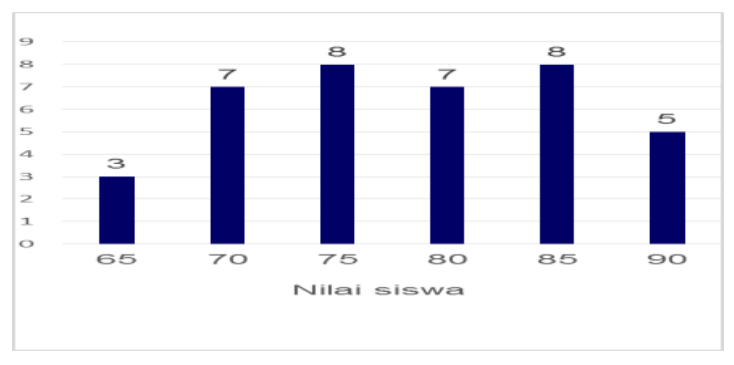

Gambar 1. Digram Batang Data Nilai Siswa pada Kelompok Eksperimen 
Sementara itu, mean pada kelompok kontrol diktegorikan kedalam Penilaian Acuan Patokan (PAP) skala lima dan menunjukkan kategori baik. Apabila divisualisasikan ke dalam bentuk diagram batang maka tampak pada gambar berikut.

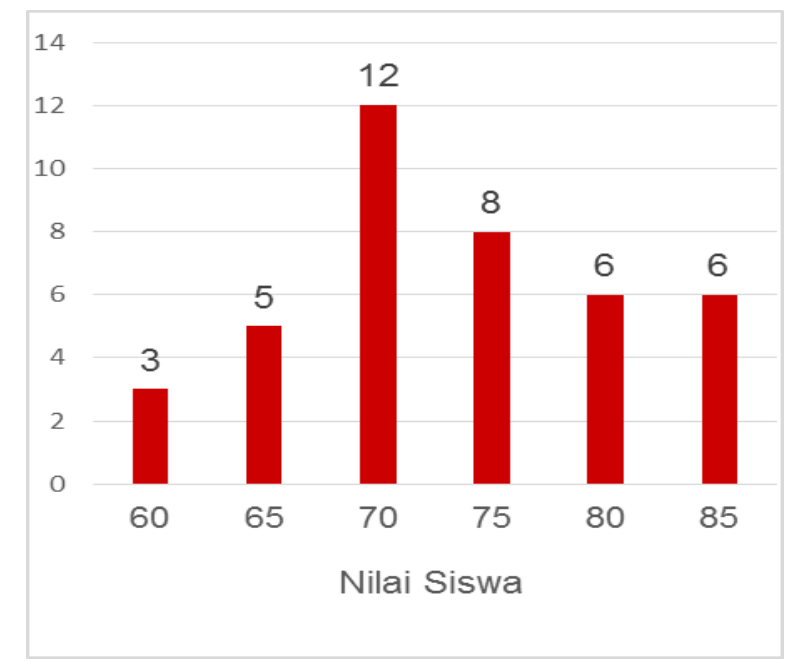

Gambar 2. Diagram Batang Data Nilai Siswa pada Kelompok Kontrol

Selanjutnya, dilakukan uji prasyarat yaitu normalitas data dan homogenitas varians. Uji normalitas dilakukan untuk mengetahui sebaran frekuensi skor pada setiap untuk menguji data penguasaan kompetensi pengetahuan IPS kelompok eksperimen dan kontrol adalah rumus Chi Kuadrat. Kriteria pengujian pada uji normalitas adalah jika $x^{2}$ hitung $<x^{2}$ tabel maka sebaran data kedua kelompok berdistribusi normal.Rekapitulasi hasil uji normalitas pada kelompok eksperimen dipaparkan pada tabel berikut.

Tabel 2. Rekapitulasi Data Uji Normalitas Data Nilai Posttest

\begin{tabular}{|c|c|c|c|c|c|c|c|c|}
\hline No. & \multicolumn{5}{|c|}{ Sampel Penelitian } & $X_{\text {hitung }}$ & $\mathrm{X}_{\text {tabel }}$ & Keterangan \\
\hline 1. & $\begin{array}{l}\text { Kelompok } \\
\text { Sesetan) }\end{array}$ & eksperimen & (SD & Negeri & 18 & 3,28 & 11,07 & Data Berdistribusi Normal \\
\hline 2. & Kelompok & zontrol (SD Ne & ri 11 & esetan) & & 3,29 & & Data Berdistribusi Normal \\
\hline
\end{tabular}

Berdasarkan hasil uji normalitas kelompok eksperimen dan kelompok kontrol, diperoleh Chi Kuadrat hitung $\left(\mathrm{x}^{2}\right.$ hitung $\left.=3,28\right)$ untuk kelompok eksperimen dan Chi Kuadrat hitung $\left(\mathrm{x}^{2}\right.$ hitung $\left.=3,29\right)$ untuk kelompok kontrol. Hasil Chi Kuadrat hitung $\left(\mathrm{x}^{2}\right.$ hitung) kelompok eksperimen dan kontrol tersebut dibandingkan dengan Chi Kuadrat tabel $\left(x^{2}\right.$ tabel= 11,07). Hal ini menunjukkan bahwa $x^{2}$ hitung $<x^{2}$ tabel yang artinya data hasil penguasaan kompetensi pengetahuan IPS kelompok eksperimen dan kontrol berdistribusi normal.

Setelah nilai posttest pada kedua kelompok dinyatakan berdistribusi normal, kemudian dilakukan uji homogenitas. Uji homogenitas dilakukan untuk menunjukkan bahwa perbedaan yang terjadi pada uji hipotesis benar benar terjadi akibat adanya perbedaan antar kelompok, bukan sebagai akibat perbedaan individu dalam kelompok. Uji homogenitas varians untuk kedua kelompok digunakan uji F. Rekapitulasi uji homogenitas dipaparkan pada tabel berikut.

Tabel 3. Rekapitulasi Data Uji Homogenitas Nilai Posttest

\begin{tabular}{ccccccc}
\hline No. & Sampel Penelitian & $\mathrm{S}^{2}$ & $\mathrm{Dk}$ & $\mathrm{F}_{\text {hitung }}$ & $\mathrm{F}_{\text {tabel }}$ & Keterangan \\
\hline 1. & Kelompok eksperimen (SD Negeri 18 Sesetan) & 80,83 & 37 & \multirow{2}{*}{0,67} & \multirow{2}{*}{1,69} & Homogen \\
2. & Kelompok kontrol (SD Negeri 11 Sesetan) & 54,41 & 39 & & & \\
\hline
\end{tabular}

Berdasarkan hasil uji homogenitas nilai posttest yang dilakukan di kelas IV SD Negeri 18 Sesetan dan SD Negeri 11 Sesetan didapat $F_{\text {hitung }}<F_{\text {tabel }}$, maka data nilai posttest kedua kelompok dinyatakan homogen. Hipotesis yang diuji dalam penelitian ini adalah tidak terdapat perbedaan yang signifikan 
penguasaan kompetensi pengetahuan IPS antara siswa kelas IV di Gugus Pattimura Tahun Ajaran 2016/2017 yang mengikuti pembelajaran menggunakan model pembelajaran kooperatif tipe STAD dan siswa yang mengikuti pembelajaran konvensional menggunakan pendekatan saintifik pada tema 9 Kayanya Negeriku. Hasil uji prasyarat yang meliputi uji normalitas dan homogenitas varians yang dilakukan dalam penelitian ini diperoleh kedua kelompok sampel berdistribusi normal dan memiliki varians yang homogen. Analisis statistik yang digunakan untuk menguji hipotesis penelitian ini adalah uji$\mathrm{t}$ dengan polled varians. Kriteria pengujian untuk $t_{\text {hitung }}<t_{\text {tabel }}$ pada taraf signifikansi $5 \%$ dengan $\mathrm{dk}=38$ $+40-2=76$ adalah 2,00. Berdasarkan hasil analisis $t_{\text {hitung }}=2,82$ yang berarti $t_{\text {hitung }}>t_{\text {tabel }}(2,64>2,00)$, maka $\mathrm{H}_{\mathrm{o}}$ ditolak.

Kelompok eksperimen pada penelitian ini dibelajarkan menggunakan model pembelajaran kooperatif tipe STAD pada kompetensi pengetahuan IPS, sedangkan pada kelompok kontrol dibelajarkan menggunakan pembelajaran konvensional menggunakan pendekatan saintifik. Berdasarkan pemaparan mengenai model pembelajaran kooperatif tipe STAD dan pembelajaran konvensional menggunakan pendekatan saintifik dapat terlihat langkah pembelajaran yang dilakukan pada kedua kelompok tersebut, sehingga mean pada kelompok eksperimen lebih besar dari kelompok kontrol. Perolehan hasil perhitungan analisis data yang dilakukan menunjukkan bahwa nilai mean siswa pada kelompok eksperimen adalah 78,29 dan pada kelompok kontrol adalah 73,38, sehingga terdapat perbedaan sebesar 4,91. Perbedaan hasil penguasaan kompetensi pengetahuan dengan perolehan nilai mean yang lebih tinggi pada kelompok eksperimen dibandingkan kelompok kontrol disebabkan oleh perlakuan berupa model pembelajaran kooperatif tipe STAD dalam muatan materi IPS diberikan pada kelas eksperimen.

Kegiatan pembelajaran pada kelompok eksperimen dalam muatan materi IPS menggunakan model pembelajaran kooperatif tipe STAD berjalan dengan optimal dan kondusif karena model merupakan suatu inovasi pembelajaran yang membentuk siswa menjadi beberapa kelompok agar saling mendorong satu sama lain untuk lebih memahami materi yang dibelajarkan. Selama kegiatan pembelajaran siswa dibentuk menjadi delapan kelompok dengan anggota empat sampai lima orang siswa yang terlebuh dahulu diawali dengan persentasi kelas oleh guru atau kegiatan diskusi pembelajaran yang dipimpin oleh guru, lalu pembentukan tim atau kelompok sehingga siswa dapat saling bekerjasama dalam memahami materi persentasi guru atau diskusi pembelajaran yang telah dilakukan. Setelah siswa diberi waktu selama beberapa menit untuk diskusi dalam kelompok mereka, guru memberikan siswa kuis yang berkaitan dengan materi pembelajaran untuk mengetahui sejauh mana kemampuan individu siswa dan kemampuan masing-masing kelompok siswa.

Kegiatan pembelajaran pada kelompok eksperimen tentunya berbeda dengan kegiatan pembelajaran pada kontrol, kegiatan pembelajaran konvensional yang menggunakan pendekatan saintifik berjalan kurang optimal. Hal ini disebabkan masih siswa yang kurang mampu mengaitkan antar materi pada muatan materi IPS dan kesulitan mengikuti setiap langkah pembelajaran yang perlu diberikan bimbingan lebih khusus. Selaim itu kegiatan pembelajaran menggunakan model pembelajaran kooperatif tipe STAD pada muatan materi IPS memberikan kesempatan memiliki beberapa kelebihan salah satunya adalah setiap siswa dapat saling bekerjasama mengisi satu sama lain (Majid, 2015:188)

Hasil temuan pada penelitian ini memiliki persamaan dengan penelitian sebelumnya yang relevan dan memperkuat hasil penelitian yang diperoleh, hal tersebut didukung oleh penelitian yang relevan, yakni penelitian yang dilakukan oleh $\mathrm{Ni}$ Kd. Ratna Wahyuni yang menunjukkan terdapat pengaruh model pembelajaran kooperatif tipe Student Teams Achievment Division (STAD) berbasis interaksi sosial tehadap hasil belajar IPS siswa kelas V Gugus 4 Widyasmara Klungkung Tahun Ajaran 2013/2014. Penelitian lain yang dilakukan oleh Komang Sudiarpa yang menunjukkan terdapat perbedaan hasil belajar IPA yang signifikan antara siswa yang mengikuti pembelajaran dengan model pembeajaran kooperatif tipe STAD dengan siswa yang mengikuti pembelajaran dengan model pembelajaran konvensional. Dengan demikian, pembelajaran menggunakan model pembelajaran kooperatif tipe STAD pada penelitian ini memiliki keunggulan yakni dapat membuat siswa lebih aktif bekerjasama dalam kelompoknya dengan membantu satu sama lain untuk menguasai materi pembelajaran yang tentunya tetap didampingi oleh guru agar kuis yang mereka kerjakan dapat memeroleh hasil yang memuaskan bagi individu maupun kelompok.

\section{Simpulan dan Saran}

Berdasarkan hasil penelitian yang telah dilakukan, diperoleh kesimpulan yaitu (1) Penguasaan kompetensi pengetahuan IPS siswa setelah dibelajarkan menggunakan model pembelajaran kooperatif tipe STAD pada siswa kelas IV SD tergolong baik dengan perolehan rata-rata nilai sebesar $78,29,(2)$ Penguasaan kompetensi pengetahuan IPS siswa setelah dibelajarkan menggunakan pembelajaran konvensional pada siswa kelas IV SD tergolong baik dengan perolehan rata-rata nilai sebesar 73,38, dan (3) Berdasarkan hasil analisis data diperoleh $t_{\text {hitung }}(2,64)>t_{\text {tabel }}(2,00)$, maka Ho yang diajukan ditolak 
dan menerima Ha. Hal ini berarti terdapat perbedaan yang signifikan pada siswa yang dibelajarkan menggunakan model pembelajaran kooperatif tipe STAD dibandingkan dengan pembelajaran konvensional. Demikian pula nilai rata-rata kelompok eksperimen lebih besar dari kelompok kontrol $(78,29>73,38)$. Dengan demikian disimpulkan terdapat pengaruh model pembelajaran kooperatif tipe STAD terhadap penguasaan kompetensi pengetahuan IPS kelas IV SD Gugus Pattimura Tahun Ajaran 2016/2017.

Berdasarkan hasil penelitian terdapat beberapa hal yang disarankan oleh peneliti. Adapun sarannya yaitu guru hendaknya memahami dan mampu menggunakan model pembelajaran kooperatif tipe STAD dalam proses pembelajaran yang bermuatan materi IPS, hasil penelitian ini hendaknya dapat menjadi alternatif dalam menyusun program pembelajaran di sekolah dan diharapkan peneliti lain pada penelitian berikutnya mampu lebih baik lagi melakukan penelitian dengan objek yang berbeda.

\section{Daftar Rujukan}

Bhoke, Wilibaldus. 2016. "Pengaruh Model Pembelajaran Kooperatif Tipe Student Teams Achievemment Division (STAD) dan Motivasi Belajar terhadap Hasil Belajar Matematika Siswa Kelas V SD Gugus 2 Kecamatan Bajawa Kabupaten Ngada- Flores", Volume 3, ISSN: 2355-5106 (hlm 106).

Giantara, I Made. 2014. "Pengaruh Penerapan Model Pembelajaran Kooperatif Tipe STAD terhadap Hasil Belajar Matematika Siswa Kelas V SD Gugus V Kecamatan Marga", Vol 2 (pg 04).

Gunawan, Rudy. 2016. Pendidikan IPS : Filosofi, Konsep, dan Aplikasi. Bandung: Alfabeta.

Kosasih, E..2016. Strategi Belajar dan Pembelajaran. Implementasi Kurikulum 2013. Bandung: Yrama Media.

Lasia, I Nyoman. 2014. "Penerapan Pendekatan Kooperatif Tipe Stad Untuk Meningkatkan Keaktifan Dan Hasil Belajar Siswa Dalam Mata Pelajran Ips Di Kelas Iii Sd Negeri 12 Padang Sambian Kota Denpasar Tahun 2013/2014", Vol 2 No 1.

Majid, Abdul. 2015. Strategi Pembelajaran. Bandung: Remaja Rosdakarya.

Malik, Oemar. 2012. Kurikulum dan Pembelajaran. Jakarta: Bumi Aksara.

Permendikbud. 2014. "Peraturan Menteri Pendidikan Dan Kebudayaan Republik Indonesia Nomor 57 Tahun 2014 Tentang Kurikulum 2013 Sekolah Dasar/Madrasah Ibtidaiyah Lampiran III" Jakarta: Kemendikbud

Permendikbud. 2014. "Peraturan Menteri Pendidikan Dan Kebudayaan Republik Indonesia Nomor 103 Tahun 2014 Tentang Pembelajaran Pada Pendidikan Dasar Dan Pendidikan Menengah". Jakarta: Kemendikbud

Permendikbud. 2014. "Peraturan Menteri Pendidikan Dan Kebudayaan Republik Indonesia Nomor 104 Tahun 2014 Tentang Penilaian Hasil Belajar Oleh Pendidik Pada Pendidikan Dasar Dan Pendidikan Menengah". Jakarta: Kemendikbud

Permendikbud. 2016. "Peraturan Menteri Pendidikan Dan Kebudayaan Republik Indonesia Nomor 20 Tahun 2016 Tentang Standar Kompetensi Lulusan Pendidikan Dasar dan Pendidikan Menengah". Jakarta: Kemendikbud

Rusman. 2014. Model-Model Pembelajaran : Mengembangkan Profesionalisme Guru. Jakarta: Rajawali Pers.

Slavin, Robert E.2016.Cooperative Learning Teori, Riset dan Praktik.Terjemahan Narulita Yusron.Cooperative Learning: theory, research and practice. 2005.Bandung:Nusa Media.

Sudiarpa, Komang, 2015. "Pengaruh Model Pembelajaran Kooperatif Tipe STAD terhadap Hasil Belajar IPA di SD No. 3 Songan", Volume 3 (pg 01). 
Sudiarsini, Made, 2016. "Pengaruh Model Pembelajaran Kooperatif Tipe STAD Berbantuan Media Visual terhadap Hasil Belajar IPA Kelas V SD”, Vol 4 (pg 01).

Sumantri, Mohamad Syarif. 2015. Strategi Pembelajaran : Teori dan Praktik di Tingkat PendidikanDasar. Jakarta: Rajawali Pers.

Susanto, Ahmad. 2014. Pengembangan Pembelajaran IPS di Sekolah Dasar. Jakarta: Kencana.

Susanto, Ahmad. 2015. Teori Belajar dan Pembelajaran di Sekolah Dasar. Jakarta: Kencana.

Solihatin, Etin dan Raharjo. 2012. Cooperative Learning : Analisis Model Pembelajaran IPS. Jakarta: Bumi Aksara

Undang-undang Republik Indonesia No. 20 Tahun 2003 tentang Sistem Pendidikan Nasional. 2003. Jakarta: Sekretaris Negara Republik Indonesia.

Utami, Santi. 2015. “ Peningkatan Hasil Belajar Melalui Pembelajaran Kooperatif Tipe Stad Pada Pembelajaran Dasar Sinyal Video", Vol : 22, No. 20. Tersedia pada https://journal.uny.ac.id/index.php/jptk/article/view/7840/6712

Wahyuni, Ni Kd. Ratna. 2014. "Pengaruh Model Pembelajaran Kooperatfatif Tipe STAD berbasis interaksi sosial terhadap Hasil Belajar IPS Siswa Kelas VSD”, Vol : 2 (pg 01)

Wulandari,Putu Yuni. 2014. "Pengaruh Penerapan Model Pembelajaran Kooperatif Tipe Team Accelerated Instruction (Tai) Terhadap Hasil Belajar IPS Siswa Kelas V SD Gugus VIII Kedewatan Kecamatan Ubud Gianyar", Vol : 2 No 1.

Yensy, Nurul Astuty. 2012. "Penerapan Model Pembelajaran Kooperatif Tipe Examples Non Examples Dengan Menggunakan Alat Peraga Untuk Meningkatkan Hasil Belajar Siswa Di Kelas Viii Smp N 1 Argamakmur", Vol : 10 . No 1. 